AKSARA: Jurnal Ilmu Pendidikan Nonformal

P-ISSN 2407-8018 E-ISSN 2721-7310 DOI prefix 10.37905

Volume 07, (03) September 2021

http://ejurnal.pps.ung.ac.id/index.php/Aksara

\title{
Genre Analysis of Memo from Headmaster to Teachers
}

\author{
Ghazi Mohammad Takal ${ }^{1^{*}}$ \\ Department of English, Faculty of Languages and Literature, Ghazni University, \\ Ghazni Afghanistan \\ Email: ghazitakal@gmail.com \\ Contact: $\mathbf{+ 9 3 7 9 6 5 2 1 0 5 8}$ \\ Mujtaba Jamal ${ }^{2}$ \\ Department of English, Faculty of Languages and Literature, Ghazni \\ University,Ghazni Afghanistan \\ Email: mujtabajamal22@yahoo.com \\ Contact: $\mathbf{+ 9 3 7 9 9 3 3 1 2 6 6}$ \\ Abdul Rahmat \\ Gorontalo State University, Indonesia \\ Email: abdulrahmat@ung.ac.id \\ * Corresponding Author
}

Received: 13 May 2021; Revised: 26 June 2021; Accepted: 14 August 2021

DOI: http://dx.doi.org/10.37905/aksara.7.3.771-780.2021

\begin{abstract}
Discourse analysis has always been a great tool for analyzing both spoken and written discourses in various discourse communities. Specifically, it has largely been used for written discourse analysis. For instance, it has been used in analysis of memos. Memos have been a valuable part of written discourse in different settings. Thus, this paper is the analysis of a memo written by a school headmaster. The author used Genre Analysis as a discourse analysis for analyzing the memo text in this paper. Although there are several models for genre analysis, Genre Analysis of Vijay. K Bhatia Model has been used in this study. The findings revealed that the memo was related to a professional genre of school while meeting not the entire characteristics of professional genre. The research suggested that future studies be conducted concerning memo analysis.

Keywords: Discourse Analysis, Genre, School, Teachers

\section{Review of Literature}

Discourse Analysis

The term Discourse Analysis has been introduced by Zellig Harris for the first time as a method for analyzing spoken and written speech (Bhatia,1993). Harris was interested in the language beyond the sentence and non-linguistic features that could be exposed through discourse analysis. While there are various definitions given to Discourse Analysis, Paltridge (2012) defines it as an investigation of patterns in a language text while taking into consideration the social and cultural contexts in which the text is used. Discourse Analysis consists of different approaches and theories for analyzing different discourses distinguished by their purposes.
\end{abstract}




\section{Genre Analysis of Vijay. K Bhatia Model}

Genre Analysis is an approach commonly employed in ESP (English for specific purposes) which comes from Swales (1990). Genre is a goal-oriented, staged, and purposeful activity which is used for getting things done in a discourse community (Palrtridge ,2012; Martin, 1984). As stated in (Bhatia, 1993). The Genre Analysis Model of Bhatia has seven principles whereas the application of all of its principles depends on the relevance of the text as Flowerdew (2002,2001) believe that analyst can use whatever steps are applying and can neglect other steps of Bhatia Model for Genre Analysis. Therefore, in this study the relevant principles will be applied and the other principles which are immaterial will be ignored. The seven steps of Vijay Bhatia Model include Placing the Given Genre-Text in a Situational Context, Surveying the Existing Literature, Refining the Situational/Contextual Analysis, Selecting Corpus, Studying the Institutional Context, Levels of Linguistic Analysis and Specialist Information in Genre. This model for genre analysis has been widely used in previous studies for different written and spoken documents' analysis. For instance, Singh, Shamsudin, and Zaid (2012) conducted a descriptive analysis consisting of move analysis and multidimensional analysis. They analyzed a written document pertinent to communicative events from engineers working at a petroleum industry in Malaysia. The findings showed that the micro and macro analyses made great contribution to preparing a satisfactory syllabus for the ESP learners. In addition, Arancón (2013) conducted an in-depth analysis to analyze the corpus of technical texts to find out how moves, steps and sub-steps work in a particular case to achieve the communicative purpose in a discourse community.

\section{Research Methodology and Procedure}

The memo used for analysis in the current study consists of 218 words, 12 sentences, and 4 paragraphs. Genre Analysis of Vijay. K Bhatia Model was used for the analysis of the memo text in this study. Vijay Model of Genre Analysis has seven steps which can be applied to various types of texts. The number of applicable steps depends on the text and the author. In this study, six steps of his model were applied. First of all, the text was counted for words, sentences, and paragraphs. Afterwards, the author chose six steps of Vijay model that were applicable to be used for the analysis for this memo text.

\section{Findings and Results}

The seven steps of Vijay Genre Analysis model were applied to analyze the memo text in the current study. The results are represented in the coming sections. Each step is explained with their relevant findings as below.

\subsubsection{Step One}

Placing the Given Genre-Text in a Situational Context: Looking at the text, the choice of words, the style, the communicative purpose it conveys, the lexis (students, teachers, school, method) reflected in the text, it is implied that it is a 
AKSARA: Jurnal Ilmu Pendidikan Nonformal

P-ISSN 2407-8018 E-ISSN 2721-7310 DOI prefix $\underline{10.37905}$

Volume 07, (03) September 2021

http://ejurnal.pps.ung.ac.id/index.php/Aksara

professional genre. It is a professional genre particularly used in a professional setting of school.

\subsubsection{Step Two}

Surveying the Existing Literature: The literature regarding the genre used in school setting shows that the genre used in the memo is similar with them. However, it lacks some parts of a professional memo such as clear organization, courtesy, and a conclusion showing what action to be taken.

\subsubsection{Step Three}

Refining the Situational/Contextual Analysis: According to Bhatia Model, this step focuses more on defining the genre-text. Here we focus on the tenor, field and mode as also suggested by Paltridge (2012). Tenor is the relationship status between people such as reader and writer, in this case, the headmaster and teachers. Field is the major or the setting where the both sides work or it can be understood as a profession, job and expertise. Mode, as the last part refers to the communication channel between those two entities involved in a communication. In this memo, the sender of the memo is a headmaster of a school and the receiver is the school teachers. It can be revealed that there have not been strong and long-term relationships between the sender and receiver since the sender (headmaster) has just moved to this new job for the last two weeks as cited in the memo. Moreover, their goals can also be different based on the perspectives of the teachers and headmaster. The headmaster would more focus on hiring the qualified, skilled and talented teachers while the teachers would not considerate to a large extent about these qualities. Hence, teachers would only prefer to be hired to gain some money. The sender and receiver relations may also be different based on the existence of opinion diversity among the receivers (school teachers) as some may prefer to serve the students better while some would like to prefer just gaining some money for their family expenses. Thus, both, the headmaster and the teachers would have distinct perspectives and goals. The fields are also different from the sender to the receiver as the sender (headmaster) relates to an administrative context while the receivers (teachers) relate to teaching discourse community. Therefore, these and other factors reveal that the relationship between sender and receiver is somewhat intricate and thus makes their goals different. As mentioned earlier, the mode of communication between the sender and readers is written and the context is a professional one which all in turn effect their perspectives from other contexts. One effect of the written channel here is that the writer may not have been such serious if the channel were spoken because he would not feel comfortable to say these words in front of the teachers. As Bhatia believes, in refining stage, we also look for the discourse patterns in terms of layout and structure, the purpose and goal of the reading and writing of the discourse should be looked upon. The memo in the current study, lacks a suitable schematic organization in the generic structure of the memo as that found in the same genres which are introduction, body and conclusion. Moreover, the memo lacks a certain and specific purpose for which it 
is written. Regarding the purpose, it is revealed that the purposes are are informative, warning and advisory. The first two purposes which are to inform and warn are mentioned at the beginning and the second is advisory shown at the later parts afterwards. The sentences "There is something intriguing about a teacher surplus which now exists in our country today. It permits us to be very selective in education. It enables us to assign teachers better. It even lets us replace some teachers we should not have hired in the first place "show the informative function and the sentences of "Teachers must show an awareness of understanding of pupils' human as well as intellectual needs. The student must have a sense of personal worth, a feeling he belongs, and some sense of power to make a difference in shaping his own destiny "show the advisory function in the memo. A comment on the wording of the memo shows that it consists of 218 words, 12 sentences, 4 paragraphs, 8 times use of modals, 2 times nominalizations, 23 times use of simple present tense and 3 times use of present perfect tense with no passivation. Some of the most recurring linguistic features used in the memo are nouns (teachers, students, students' failure, education and method) material processes (permit, replace, hire, enable) and modals (must, should, can). In terms of layout and structure, it can be argued that the memo does not have a satisfactory structure (introduction, body, and conclusion) that can suit the norms and values of the intended professional context. Bhatia's model last focus of refining analysis is on the subject or topic of the text. The topic in the memo analyzed is the issue of school teachers. The headmaster in the memo argues that the officials should be careful in hiring school teachers. The headmaster also believes that hiring new qualified teachers is so easy these days due to the excessive availability of teachers. He uses the word of "teacher surplus" which points out the excess amount. Surplus means more than amount which is used here to undermine the teaches. He then, warns the teachers through reminding them of his philosophy of education to be qualified, gain certain skills and take into consideration the specific responsibilities needed for teaching. The author is focusing more on trying to put a lot of responsibility on the shoulders of the teachers. He is trying to do all this through a non-coherent, illogical organization, informal language, serious vocabulary (must, surplus, intriguing, stimulate, and so forth) and neglecting other social and professional values. On the other hand, the memo also does not address single certain topic.

\subsubsection{Step Four}

Selecting Corpus. As mentioned earlier, the corpus of the memo shows that it relates to school genre. This can be revealed from the lexis such as " $R$ " and " $F$ " grades, students, pupils, teachers, education, failure, methods and so forth.

\subsubsection{Step Five}

Studying the Institutional Context: The fifth step towards analyzing discourse in Bhatia's model is studying the institutional setting deeply. The first point to be discussed is the structure of texts in professional settings. The language of the memo here is confusing which is not suited with the principles of memo 
writing as mentioned by Redish (1989) . Redish believes that the language of memo should be simple and should not intend to confuse the readers. The memo analyzed here sounds confusing as talking in different regards about teachers. For example, it mentions that the previously hired teachers should not have been hired while in other corner it argues that the education may be individualized and in the meantime conveys the idea of putting the entire responsibility on the shoulders of these teachers. These are some of the points that can confuse the reader teachers. Another issue in this memo is the discourteous and serious tone of the vocabulary and structure of the text. The headmaster has not been courteous in writing the memo and has maintained seriousness along the text which is contrary to the rules of memo writing as Redish (1989) argues that the memo should have a courteous tone because memos are used in professional contexts and hence they are formal.

This can be evident through the repeated use of the modals such as ' 'Must', which has been used 5 times in this 12 sentence-paragraph memo. This modal is dominantly used with the word "Teachers" which conveys here the obligation upon put on the teachers since Must shows the highest degree of obligation. For instance, one example of the sentences showing obligations is "Teachers must become more and more accountable for student's failures" and "teachers must continue to search for methods and approaches to meet the needs of students'. These and other kinds of sentences are mentioned five times with Must followed by the word "teachers". These instances reflect that the memo is intended to be very strict against teachers and views teachers sole responsible for the teaching and learning in the school context while giving no responsibility and obligation to the students or anyone else involved in the process or structure of the school. Nonetheless, the students are not given any responsibility except they are reflected with a kind of privileged entity along the text. For example, the sentence "' The student must have a sense of personal worth, a feeling he belongs, and some sense of power to make a difference in shaping his own destiny' reflect students as a dominant entity in this memo. Another modal is "Should" that is used in the beginning paragraph in this sentence "It even lets us replace some teachers we should not have hired in the first place" This modal also conveys the author's message. Here the writer shows his regret about the hiring of previous teachers. The readers can infer here that the author (headmaster) is no longer glad to work with these teachers. Thus, the writer draws the attention of readers to his education philosophy to make the readers understood about what the headmaster expects of the teachers. These all examples can convey the ideology of the headmaster as blaming teachers for every task in the school as headmaster does not mention anything about what jobs the students, school personnel, headmaster, parents of students, government officials or any other stakeholders are responsible to do. Moreover, the headmaster does not mention anything positive about the teachers. For instance, what promotions, increase in salary, facilities or anything else will be provided for the teachers. However, the author writes it in a way to undermine teachers and put every responsibility on the them. These all and other features of serious tone clearly suggest the author's ideologies as blaming teachers and putting all responsibility them. This can be also revealed from the nonuse of passive in the whole memo, thus the author wants to clearly reflect the subjects (teachers) visible 
as the ones who are responsible. Despite these, the memo also lacks a schematic structure. The memos used in professional settings possess introduction, body and conclusion with each part having a specific purpose. Nonetheless, this memo does not have such an order, thus describing the ideas randomly and without any order and professional tone. The memo here starts with the teacher surplus and then ends with points for the philosophy of education of the author. It is not written in a good order where there should be a thesis statements, body and conclusion. Also, professional memos suggest actions to be taken at the end by the audience which is also not available in this memo. Thus, the order is not available in this memo. In sum, as the tone and structure of the memo are informal that can tell us the intention of the author. The headmaster has done all this because he does not want to keep friendly relationships with the teachers because we want to be formal with people who are seniors, or strangers and show respect to them. Here the informal tone entails that the author does not want to show any respect or maintain good relationships with the teachers. Consequently, he wants to be informal and direct in his language. He tried to put the teachers under the pressure as shown by the use of modals, material processes, use of active voice, mere use of nominalization and so on.

\subsubsection{Step Six}

Levels of Linguistic Analysis. This part of Bhatia's Genre Analysis Model is the detailed one and digs deep into the text with having its three levels as mentioned before. It has the following three levels.

\section{A. Level One}

Analysis of Lexico-grammatical Features: The first focus of lexicogrammar aspect will be on the textual analysis. Some of the features analyzed here would be nouns, verbs, tense, and so on. Looking at the memo, 4 features are going to elaborated on. These are the 23 times use of 'Simple Present Tense'" 5 times use of ' 'Must', 13 Material Processes, and the nonuse of passive voice. First, the most dominant use of simple present tense denotes that the headmaster requires his teachers to bring reforms and work in accordance with the headmaster's education philosophy in the current time. The wide use of the modal "Must" shows that the headmaster is more willing for bringing the changes through putting pressure on the teachers. Moreover, the frequent use of "Material Process" also signals that something is really urged to happen and take place as material processes are used to show events, goings-on, and activities (Halliday and Matthiessen,2014). One example of material process from the memo is below where the actor is " $i t$ " referred to the "teacher surplus" and the goal is "to be very selective in education" It permits us to be very selective in education. In fact, it is the belief and ideology of the headmaster that he urges the teachers to take into consideration. He wants the teachers to suit themselves with the points mentioned in his education philosophy. Thus, reminding teachers about his educational philosophy repetitively. 
AKSARA: Jurnal Ilmu Pendidikan Nonformal

P-ISSN 2407-8018 E-ISSN 2721-7310 DOI prefix $\underline{10.37905}$

Volume 07, (03) September 2021

http://ejurnal.pps.ung.ac.id/index.php/Aksara

\section{B. Level Two}

Analysis of Text-Patterning: The linguistic features that will be elaborated on here are Nominalization, passivation, and personal pronouns used in the memo. As earlier mentioned, the memo lacks the use of any passive voice. This may be due to several reasons which could convey the author's perspective. As a matter of fact, we use active voice when we want to highlight who the subject of the action or an event is in a sentence and use passive voice to hide who the subject is. In my view, the author of the memo (headmaster) avoids the use of passivation to be clear who the subject of the action is. He wants the listener to clearly notice that the subject is the teachers who are mentioned several times in the text through the use of active voices. Thus, he wants to be very explicit in his message transferring to the audience and make the readers (teachers) understood of their actions to be taken. In addition, this could be another way for the headmaster to make the audience get message how serious and strict he is about the teachers in this context where he put more emphasis on teachers across the text. The second feature is nominalization which is a crucial part of the academic writing. Halliday (2004) sees the use of nominalization as grammatical metaphor where nouns are enabled to convey meanings beyond their normal meanings. Both (Halliday 2004) and Banks (2008) focus on the role of nominalization in academic writing. Since the author of the memo has not relied on the use of nominalization (There are only two nominalizations used "helping and understanding") and has tremendously focused on the use of verbs, it could be argued that the tone of the text is informal because nominalization is a significant part of the writing which helps the author to change actions into concepts and things so that no actions are shown. The lack of nominalization and the excessive use of material processes can be inferred as the writers' focus on the actions and events which should or must take place based on the headmasters' wishes. Another feature is the interpersonal relationships that are shown through the use of personal pronouns in the memo.

In this regard, the most dominating pronoun is " $I t$ " which is used 5 times and other pronouns are used as "Us" 4 times, "His, I, My" 2 times and "He, We, Our" 1 times respectively. Among these pronouns, the most repeated ones are " $I t$ " and "Us". The widest use of the pronoun "It" shows how much significant the notion of teacher surplus is for the author where he successively points to it four times in the first paragraph of the memo (one more time it is used as an expletive word). The second widely used pronoun is " $U s$ ". This pronoun is used as a reference to the headmaster and as a whole to the entire school administrative staff those who work as employers of the teachers. Here the headmaster uses the pronoun " $U s$ " to reflect that the ideology he is conveying in the memo is not only his but the belief and ideology of the entire administration of the school. This could also have another impact on the urgency of the issue for teachers as they would view the issue more and more serious.

\section{Level Three}

Structural Interpretation of the Text-Genre: In this part, the structure of the memo while looking at the genre of school will be discussed. As mentioned earlier, 
the memo analyzed in the current study lacks the schematic structure. For instance, the memo should start with an introduction, body and conclusion which do not exist in this memo. According to Trosborg (2000), the professional memo should start with stating the purpose in the first paragraph which shows the problem and the solution the author is going to propose. The memo here introduces three different topics at the very beginning by writing the sentences such as "There is something intriguing about a teacher surplus which now exists in our country today. It permits us to be very selective in education. It enables us to assign teachers better. It even lets us replace some teachers we should not have hired in the first place. Possibly, at long last, it can stimulate us to be serious about individualizing education" The latter paragraphs introduce the issue of teacher surplus, hiring or replacing old teachers and individualizing education which makes a kind of confusion for the readers. Hence, the reader here will not comprehend what really the issue is and what they are supposed to perform. Trosborg further states that professional memo should include what he calls "Action Items" that demonstrate what actions or steps the readers should take after reading the memo. Also this "Action Items" can answer the anticipatory questions that the readers will have. However, the memo sent by the headmaster lacks the part "Action Items" as well. In addition, the memo carries out various functions here. For instance, the function of language used in this memo is informative, directive, and advisory. This implies that there are complex functions in this memo. As a result, the structure of the analyzed memo lacks some integral prats of the real memo used in the actual professional genre.

\subsubsection{Step Seven}

Specialist Information in Genre: The last step in Bhatia Model for Genre Analysis ends with the specialist information which the researcher believes is not necessary in this study, hence all the features were applied. There is no need to refer to specialist in this case as the researcher already possess knowledge of the mentioned genre. In addition, the length of the memo used in the study is quite small which does not require specialist information.

\section{Conclusion}

This study was the analysis of a memo written by a school headmaster to his school teachers. A genre analysis of Vijay. K Bhatia Model was used to analyze the text. From Vijay model, seven steps were applied. The findings showed that the memo was from a professional genre, lacking a clear organization, and a corpus relevant to a school setting. In addition, it was found that simple present tense, modals, personal pronouns were some of the most frequent terms used in this memo. Specifically, a highlighting point was that the headmaster put all the responsibility on the shoulders of teachers. As a result, this study is paramount for the purpose of analyzing a memo which is a valuable medium of communication in academic settings such as schools. Future studies are recommend regarding memo analysis. 
AKSARA: Jurnal Ilmu Pendidikan Nonformal

P-ISSN 2407-8018 E-ISSN 2721-7310 DOI prefix 10.37905

Volume 07, (03) September 2021

http://ejurnal.pps.ung.ac.id/index.php/Aksara

\section{REFERENCES}

Arancón, P. R. (2013). New applications of genre analysis to technical manuals: the perspective of bhatian and lassen model (2012, A. Felices Lago and D. Fernández Lloret). RAEL: revista electrónica de lingüística aplicada(12), 179-180.

Banks, D. (2008). The Development of Scientific Writing. Linguistic features and historical context: Equinox.

Bhatia, V. K., \& Genre, A. (1993). Language use in professional settings. Applied Linguistics and Language Study.) London: Longman.

Flowerdew, J., \& Dudley-Evans, T. (2002). Genre analysis of editorial letters to international journal contributors. Applied linguistics, 23(4), 463-489.

Flowerdew, J., \& Peacock, M. (2001). Research perspectives on English for academic purposes: Ernst Klett Sprachen.

Halliday, M., Matthiessen, C. M., \& Matthiessen, C. (2014). An introduction to functional grammar: Routledge.

Halliday, M. A. (2004). The spoken language corpus: A foundation for grammatical theory. Language and Computers, 49, 11-38.

Halliday, M. A. K., Matthiessen, C., \& Halliday, M. (2014). An introduction to functional grammar: Routledge.

Martin, J. R. (1984). Language, register and genre. Children writing: reader, 1, 984.

Paltridge, B. (2012). Discourse analysis: An introduction: Bloomsbury Publishing.

Redish, J. C. (1989). Reading to learn to do. IEEE transactions on professional communication, 32(4), 289-293.

Singh, M. K. S., Shamsudin, S., \& Zaid, Y. H. (2012). Revisiting Genre Analysis: Applying Vijay Bhatia 's Approach. Procedia-Social and Behavioral Sciences, 66, 370-379.

Swales, J. (1990). Genre analysis: English in academic and research settings: Cambridge University Press.

Singh, M. K. S., Shamsudin, S., \& Zaid, Y. H. (2012). Revisiting Genre Analysis: Applying Vijay Bhatia's Approach. Procedia-Social and Behavioral Sciences, 66, 370-379.

Swales, J. (1990). Genre analysis: English in academic and research settings: Cambridge University Press.

Trosborg,A.(2000) Discourse Analysis as Part of Translator's Training. Arthus V : Denmark. Zellig, H. (1952). Discourse analysis. Language, 28(1), 1-30. 
AKSARA: Jurnal Ilmu Pendidikan Nonformal

P-ISSN 2407-8018 E-ISSN 2721-7310 DOI prefix 10.37905

Volume 07, (03) September 2021

http://ejurnal.pps.ung.ac.id/index.php/Aksara

780 AKSARA: Jurnal Ilmu Pendidikan Nonformal 